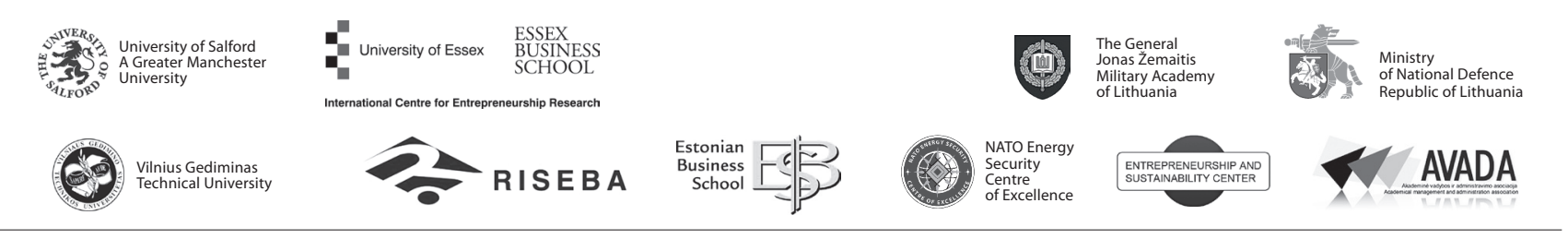

\author{
JOURNAL OF SECURITY AND SUSTAINABILITY ISSUES \\ ISSN 2029-7017 print/ISSN 2029-7025 online \\ 2018 March Volume 7 Number 3 \\ http://doi.org/10.9770/jssi.2018.7.3(5)
}

\title{
SOCIO-ECONOMIC SECURITY AS A DETERMINANT OF REGIONAL DIFFERENCES IN THE INVESTMENT CLIMATE IN THE REGION
}

\author{
Alina Ohotina ${ }^{1}$, Olga Lavrinenko ${ }^{2}$, Svetlana Ignatjeva ${ }^{3}$, Jel̦ena Lonska ${ }^{4}$ \\ ${ }^{1,2}$ Institute of Humanities and Social Sciences, Daugavpils University, \\ Parades Str. 1-421, Daugavpils, LV-5401, Latvia \\ ${ }^{3}$ Computer Science Department, Daugavpils University, Parades Str. 1-413, Daugavpils, LV-5401, Latvia \\ ${ }^{4}$ Business and Society Process Research Center, Rezekne Academy of Technologies, \\ Atbrivosanas alley 115, Rezekne, LV-4601, Latvia
}

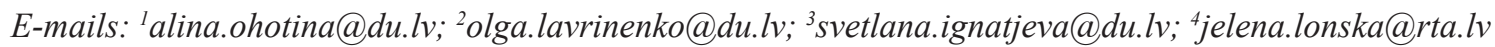

Received 10 March 2017; accepted 15 January 2018

\begin{abstract}
The issue of attracting investments is one of the key issues in modern society. The global experience shows that sustainable economic development and growth are determined by the volume and structure of investments. Therefore, the study into the investment environment where the investment activity happens - the investment climate, is becoming increasingly relevant. The prerequisites for the study into the investment climate have been formed since the Keynesian economic theory; studies into the investment climate have become widely spread in modern economic theories. Starting with the Keynesian economic theory and until modern theories of investments, the factors that influence the investment climate can be divided into two groups: investment potential and investment security of the region. According to the outcomes of the factor analysis of Latvia's regions (Riga, Pieriga, Vidzeme, Kurzeme, Zemgale, and Latgale regions), Lithuania's regions (Vilnius, Alytus, Utena, Panevezys, Kaunas, Klaipeda, Marijampole, Taurage, Telsiai, Sauliai counties), and Belarus' regions (Vitebsk, Grodno, Mogilev, Minsk, Gomel, and Brest oblasts, and Minsk city), the factor of socioeconomic security is adeterminant of regional differences in the investment climate.
\end{abstract}

Keywords: investment climate, investment potencial, investment security, sustainability

Reference to this paper should be made as follows: Ohotina, A.; Ignatjeva, S.; Lavrinenko, O., Lonska J. 2018. Socioeconomic security as a factor of the investment climate in the region, Journal of Security and Sustainability Issues 7(3): 427-438. http://doi.org/10.9770/jssi.2018.7.3(5)

JEL Classifications: L26, M21, O11, R11.

\section{Introduction}

As the global experience shows, the region's sustainable development considerably affected by the business envirom (Tvaronavičienė, Lankauskienė 2011; Šimelytė, Antanavičienè 2013; Tvaronavičienè et al. 2013; Pietrzak et al. 2017; Lincényi M. 2017; Petrenko et al. 2017; Menshikov et al. 2017; Tvaronavičiené, Gatautis 2017).Economists started to get interested in the study into the environment where investment processes happen in the classic economic theory (Smith 2007; Petty, Smith, Ricardo 1993), but in the study into the investment climate starting from the Keynesian economic theory (Keynes 2013). J.Keynes (2013) carried out the analysis of the investment activity and its factors at macro and micro levels. The inequality in the distribution of 
investments and their peculiarities encouraged the study into the factors of environment where the investment activity happens. Since the beginning of the 21 st century, scientists have started actively to study the factors which influence the favourableness of the investment climate (Titarenko 2006; Dubra, Gulbe 2007; Liepina, Coolidge, Grava 2008; Karačuns 2010; Hiḷkevičs, Štefenberga 2013; Gaspariene 2015; Pietrzak et al. 2017). There are also a number of research projects for the study into the factors of the investment climate. Here, we can mention the projects implemented in Latvia: "Investment Climate and Busienss Environment in Latvia" (TNS Latvia, 2008); "Entrepreneur Survey on the Influence of Administrative Reforms on the Business Environment in Latvia", "The Independent Assessment of the System for Investment Attraction", "Obstacles for Business in Latvia" (LR Ekonomikas ministrija, 2012 a, 2012 b, 2014; 2016); "Research on Prospective Places (Territories) in Vilani Municipality for Attracting Investments and Opportunities for Their Development" (INTRA Investigation \& Training, 2012); "Business Environment in Jurmala City" (SIA "Investīciju Risinājumu Birojs", 2013); "FICIL Sentiment Index" (Foreign Investors Council in Latvia, 2017). The study into the investment climate at a regionl level is especialy relevant, as the country's investment climate indicator is not an average indicator of the regions comprising it. (Andrianov 2007; Asaul, Karpov, Perevyazkin, Starovoytov 2008; Raluca Danciu 2010; Obukhova, Mashkina 2014; Hildebrandt 2015; Ohotina 2017).

All the abovementioed defined the aim of the article, which is to develop the methodology and assess the investment climate in Latvia's, Lithuania's, and Belarus' regions, as well as to identify the factors that determine the regional differences in the investment climate. In order to achieve the research aim, it is necessary to perform a number of tasks:

- to develop the methodology for the assessment of the investment climate and to approve it in Latvia's, Lithuania's, and Belarus' regions;

- to determine the factors that determine regional differences in the investment climate in the abovementioned regions.

Within the frameworks of this article, the investment climate has been assessed as an integrated and complex phenomenon that requires the elaboration of the methodology for convolution of a multi-dimensional concept into a scalar. Therefore, the authors developed an integral indicator of the investment climate in Latvia, Lithuania, and Belarus on the basis of objective statistical data.

\section{Methodology and Research Method}

Economists in the classical economic theory started to get interested in the factors that influence the environment where the investment processes happen. A. Smith (2007) studied factors that influence the investment process at the micro and macro levels, specifically part of the capital that is invested into production. A. Smith noted the subjectivism of an entrepreneur's intention to invest his capital in production. In A. Smith's theory, the process of conversion of resources into profit is influenced by labour, innovation, production, consumption, natural-resource, infrastructure, and financial types of potential, as well as social, economic, criminal, legislative, and finance risks. D. Ricardo continued studying the factors of the investment process started by A. Smith. In D. Ricardo's theory, the process of conversion of resources into profit is influenced by the following types of potential - labour, natural-resource, production, innovation, and finance and the following types of risk - legislative, social, criminal, and finance (Petty, Smith, Ricardo 1993). J. S. Mill (2016) continued the study of the factors of the investment process. The economist also emphasized subjectivism and an entrepreneur's intention to invest his capital into production. J. S. Mill marked the production potential as the most significant factor that influences the capital, as well as the following types of potential - labour, consumption, natural-resource, and finance. He also talked about the following types of risks - legislative, criminal, ecological, political, and financial.

Later, in the neoclassical economic theory a wider range of the factors of investment activity at the micro and macro levels was studied as compared to the representatives of the classical economic theory. According to L. Walras's (2003) theory of general economic equilibrium, in the process of capitalization, it is achieved as a result of interaction between production and consumption potentials. A. Marshall (2006) emphasized the 
role of subjective psychological factors influencing the process of investment of capital. The economist refers innovation, institutional, consumption, production, natural-resource and labour types of potential as well as social, economic, and legislative risks to significant factors that influence capital. A. Pigou (2005) highlighted the significance of subjective psychological factors, as well as a risk constituent on the investment process. The scientist said that the influence of risks on this process is significant but he did not distinguish the types of risks. A. Pigou referred infrastructure, production, labour and innovation types of potential to the factors that influence capital.

J. Keynes (2007) when analysing the factors that influence investments complemented microeconomic factors with macroeconomic ones. Labour potential in the form of revenue position, consumption, production, innovation types of potential, as well as financial, ecological, and economic types of risk influence the decision to invest. J. Keynes highlighted a group of subjective factors that influence the investment process. The economist formulated the multiplier effect of the influence of investments on the GDP; he also noted the need for analysis of conditions of the investment process. It should be noted that J. Keynes was the first who established the preconditions for the paradigm of investment climate in its modern understanding.

The factors of investment processes are studied at the micro and macro levels in dynamics in modern neoclassical theories of neo-liberalism. J.R. Hicks (2009) studies the factors that influence investments from the perspective of microeconomic analysis of the firm's capital and income maximization. The economist interprets the factors of the investment process in the long run. An innovation potential turns out to be the key factor in the decision to invest; production and financial potentials, and a financial risk also influences this process. R. Harrod (2011) continues the approach of the neo-classical theory and the study of investment factors in the long-term period. R. Harrod distinguishes 3 groups of factors that influence individual, corporate and government savings. Individual savings are influenced by labour and consumption potentials; corporate savings are influenced by financial, labour, and innovation potentials; government savings are influenced by financial potential, especially by the export volume. R. Harrod (2011) believes that the increase in export promotes internal investments with a multiplier effect. In A. Hansen's (2008) cycle investment theory, a financial potential (the correlation between the profit margin and interest rate), innovation, labour, and consumption potentials are the factors that influence the change in the investment volume. Changes in the investment volume in their turn influence business cycle fluctuations, including revenue and employment. Modern neo-classical theories of monetarism study the factors of investments and their increase in the future.

M.Friedman (1994) distinguishes 5 types of investments - money, bonds, stocks, physical benefits, and human capital that respectively produce different types of profit. The economist distinguishes financial, consumption, and labour potentials, and financial and legislative risks as factors that influence investments in the long-term period. P. Samuelson (2010) distinguishes 3 types of investments according to the subject that makes them private persons, a group of private persons, or an enterprise. The factors that influence the volume of investments are the following: labour, innovation, and production potentials, and political, legislative, and financial risks. Investments in their turn have a multiplier effect on revenue and employment.

In the FDI theory among the FDI factors and their successful attraction the higher risks as compared to other types of investments are distinguished - first of all, political risks, as well as legislative, financial, economic, and social risks (Eriňš, Orlovska 2006). As was mentioned earlier, the influence of the FDI on economy and sustainable development is huge, therefore, the environment factors - ecological risks and natural-resource potential are also added to socio-economic factors of the FDI - production, labour, financial, innovation types of potential, and social, economic, and financial types of risks (Tvaronavičienė, Lankauskienė 2011; Tvaronavičienė et al. 2009; Šimelytė, Antanavičienė 2013). The main factors that determine the inequality of investment activity in the regions are examined from the viewpoint of macroeconomic and institutional positions. Stable economic and financial factors are the factors of the growth in investments. The differences in the volume of investments are determined by geographic, production and resource, technological, production, and infrastructure factors (Titarenko 2005). The authors also note the strong influence of innovation (R\&D) potential on the investments in the regions (Iwasaki, Suganuma 2015). 
Starting from the classical economic theory and until modern theories of investments, factors that influence the investment climate can provisionally be divided into two groups - investment potential and investment security in the region. The region's investment potential is a total of objective economic, social, and natural and geographic features of the region that are of great significance for attracting investments to the region. The given category represents a qualitative characteristic that considers basic macroeconomic features in the form of the total of objective prerequisites for investments and depends on the availability and variety of spheres and objects for investment as well as the economic development in the region. In other words, it is the total of factors that attract or repel investors; it is the whole of objective prerequisites for the inflow or outflow of investments. Investment security is the total of factors which influence the possibility for emerging unpredicted financial losses in the conditions of the uncertainty of the outcomes of investment activity or the possibility for full or partial failure to achieve the outcomes of investment activity.

On the basis of the analysis of the sources on the investment theory, and the risk approach towards understanding the investment climate, the authors distinguished various types of the investment potential that influence the favourableness of the investment climate: natural-resource, labour, infranstructure, production, consumer, finance, institutional, innovation, tourist, as well as various types of the investment security: political, social, economic, ecological, criminal, financial-legislative (see Figure 1):

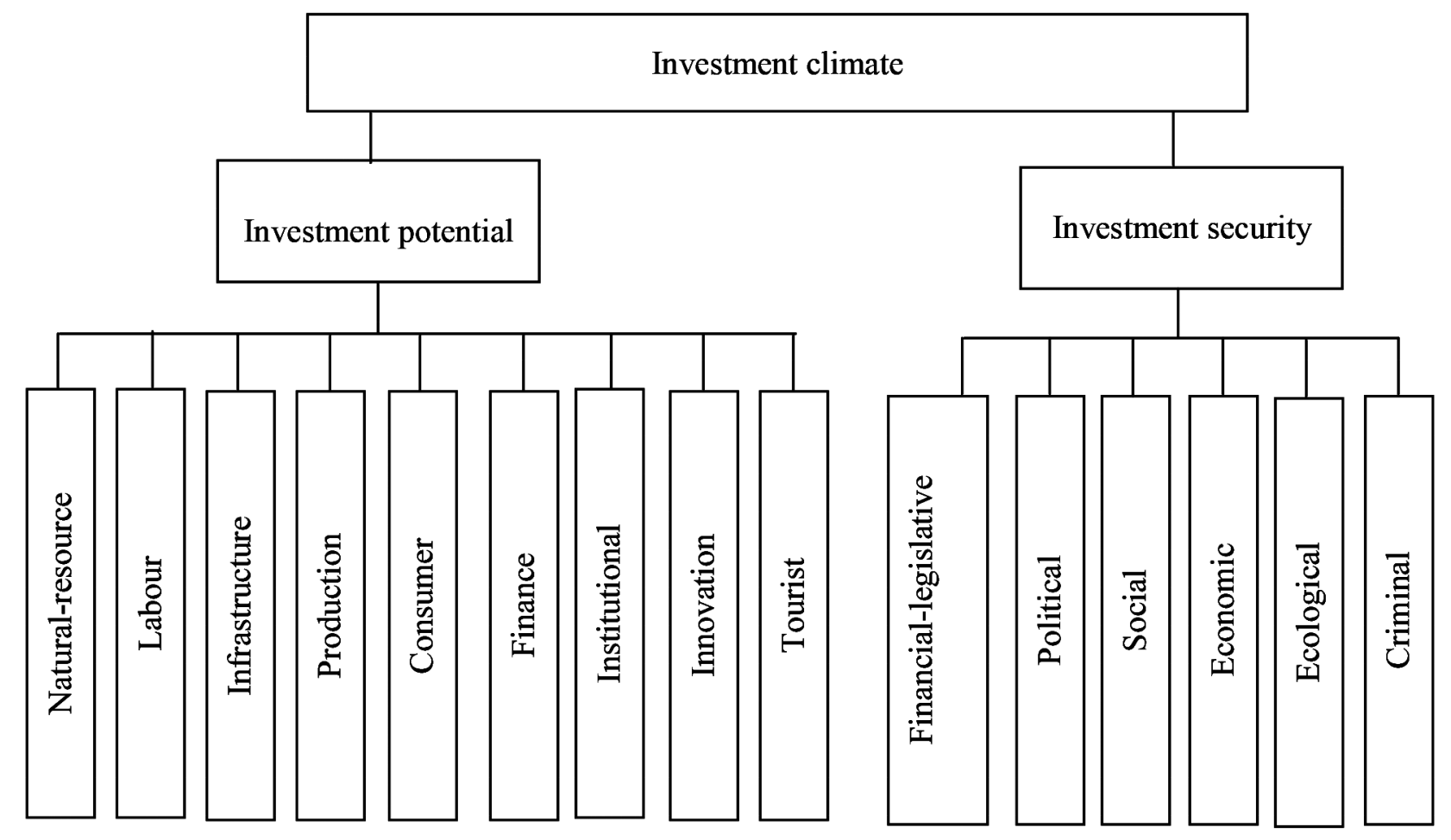

Fig. 1. Structure of factors of the investment climate

Source: the authors' drawing based on the literature analysis (Smith, 2007; Keynes, 2007; Titarenko, 2005; T.McKinnish, 2005; Tvaronavičienė et al. 2009; Obukhova, Mashkina, 2014; Pietrzak et al., 2017)

These factors predetermine the attractiveness and feasibility of investing in one or another territory (Weingast, 1995; Titarenko 2005; Perry 2015; Ohotina 2017; Pietrzak et al. 2017). Below, there are statistical indicators of the factors according to which the assessment of the investment climate in the regions under study has been carried out (see Table 1). 
Table 1. Set of statistical indicators of the investment climate

\section{Investment potential \\ $\mathbf{p}_{1}$ - Natural-resource potential}

$\mathrm{p}_{1.1}$ - the area of a region territory in proportion to the area of the territory of Latvia, Lithuania, Belarus; the structure of the land area, $\%: \mathrm{p}_{1.2}-$ agricultural lands; $\mathrm{p}_{1.3}-$ lands with marshes and waters; $\mathrm{p}_{1.4}-$ wooded lands; $\mathrm{p}_{1.5}-$ other lands.

\section{$\mathbf{p}_{2}$ - Tourist potential}

$\mathrm{p}_{2.1}$ - number of museums per 100,000 people; $\mathrm{p}_{2.2}$ - number of theatres per 100,000 people; $\mathrm{p}_{2.3}$ - number of museum visits per 1,000 people; $\mathrm{p}_{2.4}$ - number of theatre visits per 1,000 people; $\mathrm{p}_{2.5}$ - number of culture centres per 100,000 people; $\mathrm{p}_{2.6}$ - number of hotels per 100,000 people; $\mathrm{p}_{2.7}$ - hotel capacity, average number of rooms per 1 hotel; $\mathrm{p}_{2.8}$ - number of rural guest houses per 100,000 people; $\mathrm{p}_{2.9}$ - number of tourist organizations per 100,000 people.

\section{$\mathbf{P}_{3}$ - Labour potential}

$\mathrm{p}_{3.1}$ - density of population; $\mathrm{p}_{3.2}-$ natural population growth; $\mathrm{p}_{3.3}-$ migration balance; $\mathrm{p}_{3.4}$ - working-age population; $\mathrm{p}_{3.5}-$ infant life expectancy; $\mathrm{p}_{3.6}$ - employment level; $\mathrm{p}_{3.7}$ - economic activity; $\mathrm{p}_{3.8}-$ number of students at higher education (colleges, universities) per 10,000 people.

\section{$P_{4}$ - Infrastructure potential}

$\mathrm{p}_{4.1}$ - density of roads, $\mathrm{km}$ per $1,000 \mathrm{~km}^{2} ; \mathrm{p}_{4.2}$ - number of educational establishments (colleges, universities) per 100,000 people; $\mathrm{p}_{4.3}$ - number of libraries per 100,000 people; $\mathrm{p}_{4.4}$ - number of secondary schools per 100,000.

\section{$\mathbf{P}_{5}$ - Production potential}

$\mathrm{p}_{5.1}-$ GDP per capita.

\section{$\mathbf{P}_{6}$ - Consumer potential}

$\mathrm{p}_{6.1}$ - average salary (gross); $\mathrm{p}_{6.2}$ - average retirement pension; $\mathrm{p}_{6.3}-$ average income per 1 household member; $\mathrm{p}_{6.4}-$ availability of automobiles per 1,000 people.

\section{$P_{7}$ - Finance potential}

$\mathrm{p}_{7.1}$ - amount of FDI stock per resident; $\mathrm{p}_{7.2}-$ non-financial investments, in actual regional price in relation to general volume.

\section{$\mathbf{P}_{8}$ - Institutional potential}

$\mathrm{p}_{8.1}-$ total number of enterprises per 1,000 people; $\mathrm{p}_{8.2}-$ number of micro-enterprises; $\mathrm{p}_{8.3}-$ number of small enterprises, $\mathrm{p}_{8.4}-$ number of middle-sized enterprises; $\mathrm{p}_{8.5}$ - number of large enterprises.

\section{$\mathbf{P}_{9}$ - Innovation potential}

$\mathrm{p}_{9.1}-$ number of science-research centres per 100,000 people; $\mathrm{p}_{9.2}-$ number of staff employed at science-research centres out of the number of total population.

\section{Investment security}

$R_{1}$ - Social security

$r_{1.1}$ - pre- working-age population; $r_{1.2}$ - coefficient of potential demographic burden; $r_{1.3}$ - coefficient of pensioner demographic burden; $r_{1.4}$ - number of divorces per 100 marriages; $r_{1.5}$ - divorce rate coefficient (number of divorces per 1,000 population); $r_{1.6}-$ mortality rate coefficient (number of deaths per 1,000 people).

\section{$\mathbf{R}_{2}$ - Economic security}

$r_{2.1}$ - unemployment rate; $r_{2.2}$-youth unemployment rate; population with the shortage of financial resources for, $\%: r_{2.3}-$ buying meat and fish produce at least once a week; $r_{24}$ - timely payment for housing and utility services; $r_{25}$ - purchase of fuel (if there is no central heating); $\mathrm{r}_{26}$ - payment for unanticipated needs if required.

\section{$\mathbf{R}_{3}$ - Ecological security}

$\mathrm{r}_{3.1}-$ tons in average per $1 \mathrm{~km} 2$; air pollution emissions $\%: r_{3.2}-$ solid; $r_{3.3}-$ sulphur dioxide; $r_{3.4}-$ carbon oxide; $r_{3.5}-$ nitrogen dioxide; $\mathrm{r}_{3.6}$ - nonmethane volatile organic compounds; $\mathrm{r}_{3.7}$ - other types of pollution

\section{$\mathbf{R}_{4}$ - Criminal security}

$\mathrm{r}_{4.1}-$ number of reported crimes per 10,000 people; $r_{4.2}-$ road traffic accidents per 10,000 people

\section{$\mathbf{R}_{5}$ - Financial- legislative security}

$\mathrm{r}_{5.1}-$ inflation; $\mathrm{r}_{5.2}-$ number of closed down enterprises

\section{$R_{6}$ - Political security}

$\mathrm{r}_{6.1}-$ expert assessment 
While collecting statistical data from the regions in Latvia, Lithuania, and Belarus, the national data bases were used - the Central Statistical Bureau of Latvia, the Lithuanian Department of Statistics, the National Statistical Committee of the Republic of Belarus Belstat, the data from the ministries of the countries under study, collections of statistical data that characterize social and economic development of the regions under study; the statistical base of the European Statistical Agency Eurostat for the EU regions. In order to assess political security of the territory under study the author interviewed six international experts.

The comprehensive assessment of the investment climate has been identified on the basis of the sum method, by means of summing up true values of indicators of generalized investment potential and generalized investment security according to the following formula (1):

$$
x_{i}=\sum_{j=1}^{9} p_{i j}+\sum_{j=1}^{6} r_{i j}
$$

Where $i=\overline{1, n}, x_{i}$ - the comprehensive assessment of the investment climate for the region "i"; $p_{i j}^{\prime}-$ the value of investment potential where the types of investment potentials $j$ are calculated as the sum of statistical indicators; $r_{i j}^{\prime}-$ the value of investment security where the types of investment security $j$ are calculated as the sum of statistical indicators.

The unification was carried out using a formula (2), (3):

- for the indicators of investment potencial as a stimulant $p_{i j}^{\prime}=\frac{p_{i j}-p_{\min j}}{p_{\max j}-p_{\min j}} \cdot 10$

- for the indicators of investment security as a destimulant $r_{i}^{\prime}=\frac{r_{\max }-r_{i}}{r_{\max }-r_{\min }} \cdot \mathbf{0}$

\section{Research results}

The classification of Latvia's, Lithuania's, and Belarus' regions has been carried out in accordance with the calculated values of the integral index with the help of dividing a number of values into quintiles, where the regions with a very unfavourable investment climate fall into the $1^{\text {st }}$ group, but the regions with a very favourable investment climate fall into the $5^{\text {th }}$ group (see below Figure 2).

According to the authors' calculations, it can be seen that on the basis of the values of the integral index of the investment climate, the following regions fall into the quintile group 1 with a very unfavourable investment climate: Brest, Vitebsk, Grodno and Mogilev oblasts; Latgale region, Marijampole and Siauliai counties, Gomel and Minsk oblasts fall into the quintile group 2 with an unfavourable investment climate; Alytus, Panevezys, Taurage, Telsiai, and Utena counties fall into the quintile group 3 with an average level of the investment climate; Kurzeme, Pieriga, and Zemgale regions, Klaipeda and Kaunas counties fall into the quintile group 4 with a favourable investment climate; the capital city regions such as Riga region, Vilnius county, Minsk city, and Vidzeme region fall into the quintile group 5 with a very favourable investment climate. 


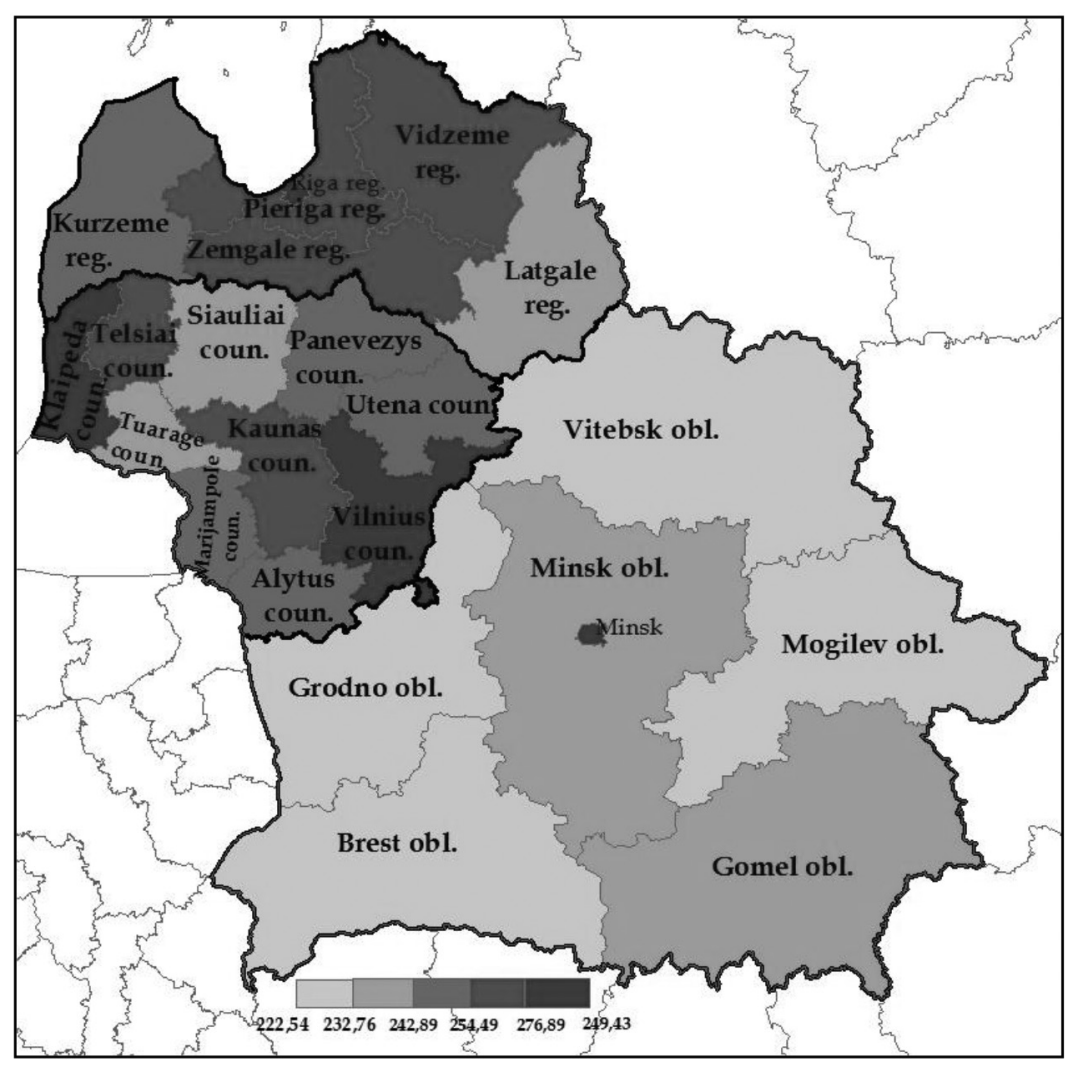

Figure. 2. Map of the classification of Latvia's, Lithuania's, and Belarus' regions according to the value quintiles of the overall index of the investment climate

Source: the authors' figure drawn in ArcGis 10 programme according to the calculations of the statistical data of Latvia's, Lithuania's, and Belarus' regions applying the elaborated methodology for the assessment of the investment climate

In order to identify latent factors that determine territorial differences in the investment climate, the authors carried out a factor analysis in the dimension of the indicators "investment potential" and "investment security". The factor analysis was carried out with the selection of the factors by the method of principal components and further Varimax-rotation (Extraction Method: Principal Component Analysis. Rotation Method: Varimax with Kaiser Normalization). Varimax orthogonal rotation with the minimization of a number of variables with a high factor loading is most frequently applied as it makes the interpretation of the factors easier. Apart from that, factors determined by this way weakly correlate together. The criterion of Kaiser-Meyer-Olkin Measure of Sampling Adequacy is 0.7 , which proves the feasibility of the application of the factor analysis for the analysis of the assessment structure.

The factor analysis revealed two latent factors with the common percent of total dispersion explained by the determined factors of $71.12 \%$ :

- F1 - socio-economic security and infrastructure;

- F2 - innovation- production potential.

The first determined F1 factor explains $39.87 \%$ of total dispersion and its semantics is explained by such main factors as "financial-legislative security" with the factor loading of 0.979 ; "consumer potential" -0.901 ; "infrastructure potential" - 0.801; "institutional potential" - 0.721; "ecological security" - 0.707; "social security" -0.577 .

The second factor F2explains $31.25 \%$ of total dispersion and its semantics is explained by such factors as "innovation potential" with the factor loading of 0.951 ; "fianncila potential" - 0.935 ; "production potential" 0.710; Tourism potential" - 0.646; "labour potential" - 0.578 . 
After having done the cluster analysis on the latent factors, the following drawing has been made (see Figure 3):

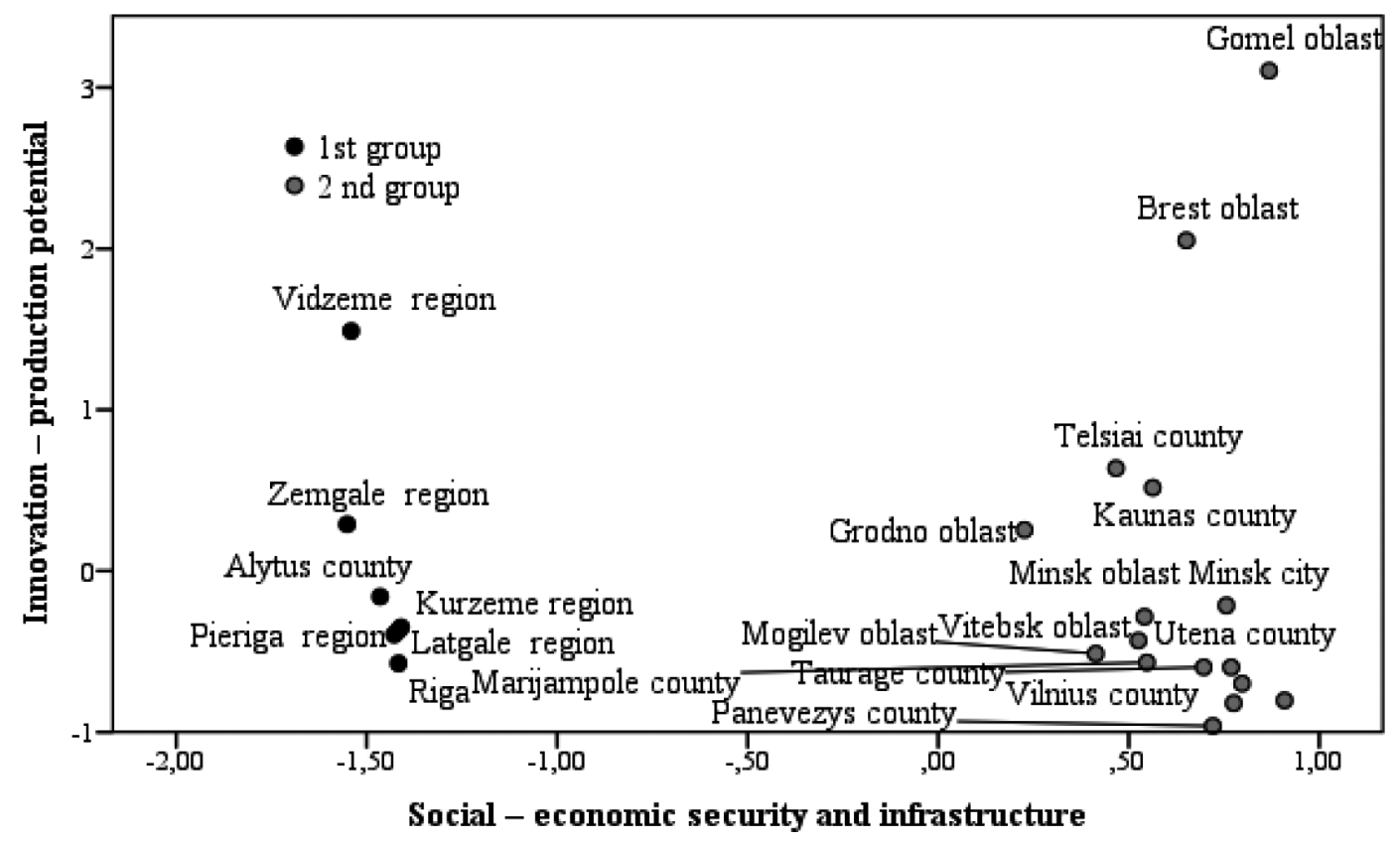

Fig. 3. Distribution of regions according to the clusters (groups) determined in the dimension of F1 and F2 factors.

Source: the authors' calculations of the statistical data of Latvia, Lithuania, and Belarus regions applying the elaborated methodology for the assessment of the investment climate

According to the outcomes of the cluster analysis on the two determined factors - socio-economic security and infrastructure and innovation-production potential, Latvia's, Lithuania's, and Belarus' regions are divided into 2 groups. All Belarus' regions fall into group 1 with the low value of the socio-economic security and infrastructure factor. Latvia's and Lithuania's regions fall into group 2 with the high value of the socio-economic security and infrastructure factor. According to the innovation-production potential, the metropolitan regions of these countries with the highest assessment of this factor are distinguished - Riga region, Vilnius county, and Minsk city. The value in other regions is low. Therefore, it is the first factor-socio-economic security and infrastructure that is a latent factor which determines regional differences in the investment climate.

\section{Conclusions and discussion}

The authors found out that the socio-economic security and infrastructure is a determinant of regional differences in the territories under study. All Belarus' regions are characterized by a low level of socio-economic security and infrastructure. Therefore, in order to improve the investment climate in Belarus' regions, the government should provide the enhancement of security by means of the further integration into the international economy, participation in various forums of international, regional, and bilateral cooperation, assisting democratic reforms, providing political stability and encouraging the establishment of trust. It is necessary to provide a stable legal system, to support the transparency of processes via E-government, publication of administrative decisions and mainteinance of an open systematic dialogue with a private sector, to promote open privatization and decrease in bureaucracy. These methods and other methods of the efficient management can send a clear message to foreign companies that the corresponding country values its contribution into the public welfare and will cooperate with them in order to achieve a mutual benefit.

The outcomes of the research are congruent with the findings of similar research in this spehere. A.Sayapin (Sayapin 2011) believes that transparency, stability and predictability are irreplaceable foundations for the economic development. If there is lack of these main political and legal features, the boosters such as plentiful natural resource, low taxes, or low cost of labour that are normally useful for the economic growth will not 
be as efficient as they could be. Since political instability and inadequate security violate most of legitimate processes of business activity, governments should set the provision of civil, political, and economic rights and freedoms as their high priority task (Michael G. Parisi 2005). In addition to the provision of human rights and crime prevention, government should prevent any violent or uncompensated withdrawals of foreign and internal investments, discriminatory sanctions and government interventions. Governments can improve their transparency and legislative compliance with global or regional standards in commercial law by publishing laws, regulations and executive decisions, as well as by providing the period of notification until the final adoption of laws and regulations.

According to the research on global prospects for the distribution of direct foreign investments "Best-Practice Guide for a Positive Business and Investment Climate" $81 \%$ of the respondents mentioned a terrorism threat, and $71 \%$ pointed at the legislative instability as the main factors that negatively influence flows of investments (Organization for Security and Co-operation in Europe 2006). They say that investors are unable to forecast their profit under a constantly changing legislation system. A stable macroeconomic policy inspires investment activity (World Bank 2005; Easterly 2001). Economies which demonstrate growth and stability provide the highest level of opportunities and they will attract significant investments. Open economies have more chances for success: liberalization of trade, free flow of capital and free movement of labour also encourage economic activity.

The quality of a country's infrastructure - roads, transport networks, water supply, telecommunication networks, public work and services, customs system, education system are also of crucial importance for attracting foreign investments. Transport and communal infrastructure are the most important one as investors need to have the opportunity to supply and move their products to the market as soon as is reasonably possible and by the most effective way (World Bank Development Report 2005).

\section{References}

Andrianov, A. Yu. i dr. 2007. Investitsii [Investments]. Moskva.

Asaul, A. N.; Karpov, B. M.; Perevyazkin, V. B.; Starovoytov, M. K. 2008. Modernizatsiya ekonomiki na osnove tehnologicheskih innovatsiy [Modernization of the economy based on technological innovations]. SPb: ANO IPEV.

Dubra, E.; Gulbe, M. 2008. Forecasting the Labor Force Demand and Supply in Latvia. Technological and Economic Development of Economy. Baltic Journal on Sustainability 14(3): 279-299.

Easterly, W.; Levine, R. 2001. It's Not Factor Accumulation: Stylized Facts and Growth Models. World Bank Economic Review 15(2):177-219.

Erinšš, I.; Orlovska, A. 2006. Ārvalstu tiešo investīciju ietekme uz Latvijas ekonomisko stāvokli [Influence of Foreign Direct Investment on Latvia's Economic Situation]. Ekonomiskie pētījumi uzņēmējdarbībāa, Nr. 4, 52.-63.

Friedman, M. 1994. Money Mischief: Episodes in Monetary History Paperback. London. A Harvest book. Harcourt Brace \& Company

Gaspariene, L. 2015. The analysis of Investment Enviroment and Foreign Direct Investment Prognostication: Lithuania Case. Mykolas Romeris University, 12-17.

Hansen, A.H. 2008. Business Cycles and National Income. New York. Norton Company INC.Harrod, R. 2011. Economic Dynamics. Macmillan.

Hicks, J. 2009. Value and Capital: An Inquiry into Some Fundamental Principles of Economic Theory. Clarendon Press

Hildebrandt A.; Nowicki M.; Susmarski P., Tarkowski M., Wandałowski M. 2015. The Investment Attractiveness of the Regions and the Sub-Regions of Poland. Ed. M Novocki. Gdansk, Gdansk Institute for Market Economics.

Hiḷķevičs, S.; Štefenberga D. 2013. Inovatīvā uzṇēmējdarbība Latvijā: sasniegumi un izaicinājumi. [Innovative Business in Latvia: Achievements and Challenges]. Starptautiskā zinātniskā konference „Sociālās zinātnes regíonālajai attīstībai 2013”. Daugavpils Universitātes Sociālo zinātṇu fakultāte, Daugavpils, Latvija, 2013. g. 10.-12. Oktobrī 
INTRA Investigation \& Training. 2012. Pētījums par Viḷānu novada perspektīvajām investīciju piesaistīšanas vietām (teritorijām) un to attīstības iespējām [Study on Prospective Investment Attracting Places (Territories) Of Vilani Region and its Development Possibilities]. Available on the Internet: http://www.sif.gov.lv/nodevumi/nodevumi/5104/Investiciju_-petijums_Vilani_Final.pdf

Iwasaki I.; Suganuma, K. 2015. Foreign Direct Investment and Regional Economic Development in Russia: Econometric Assessment. Economic Change and Restructuring 48 (3), 209-255.

Karačuns, V. 2010. Labvelīga investīciju klimata veidošanas galvenās sakarības Latvijā. [The Main Correlation of Favourable Investment Climate in Latvia]. Latvijas ekonomiskās izaugsmes faktori un perspektīvas: zinātniskā semināra materiāli. Red. L. Ādamsone. Rīga, RTU izdevniecība, 13-20

Keynes, J.M. 2013. The General Theory of Employment, Interest and Money. The Postulates of the Classical Economics. King's College, Cambridge.

Latvijas Respublikas Ekonomikas ministrija. 2012a. Uzņēmēju aptauja par administratīvo procedūru ietekmi uz uzņēmējdarbības vidi Latvijā un reformu ziņojums. [Entrepreneur Survey on the Impact of Administrative Procedures on the Entrepreneural Environment in Latvia and the Reform Report]. Available on the Internet: https://www.em.gov.lv/lv/nozares_politika/nacionala_industriala_politika/ petijumi/

Latvijas Respublikas Ekonomikas ministrija. 2012b. Investīciju piesaistes sistēmas neatkarīgs novērtējums [Independent Assessment of the Investment Attracting System]. Available on the Internet: https://www.em.gov.lv/lv/nozares_politika/nacionala_industriala_politika/petijumi/

Latvijas Respublikas Ekonomikas ministrija. 2014. 2014.gada uzņēmumu aptauja par administratīvo procedūru ietekmi uz uzņēmējdarbības vidi Latvijā [Entrepreneur Survey on the Impact of Administrative Procedures on the Entrepreneural Environment in Latvia in 2014]. Available on the Internet: https://www.em.gov.lv/lv/nozares_politika/nacionala_industriala_politika/petijumi/

Latvijas Respublikas Ekonomikas ministrija. 2016. Uzņēmējdarbības škēršlıi Latvijāa [Entrepreneurship barriers in Latvia]. Available on the Internet: https://www.em.gov.lv/lv/eiropas_savieniba/zino_par_skersliem/

Liepina, S.; Coolidge, J.; Grava, L. 2008. Improving the Business Environment in Latvia: the Impact of FIAS Assistance. Foreign Investment Advisory Service (FIAS) occasional paper; no. FIAS 18. Washington, DC: World Bank. Available on the Internet: http:// documents.worldbank.org/curated/en/2008/01/8900741/improving-business-environment-latvia-impact-fias-assistance

Lincényi, M. 2017. Entrepreneurship ecosystem facets: the European migrant crisis and public opinion in Slovakia, Entrepreneurship and Sustainability Issues 5(2): 357-367. https://doi.org/10.9770/jesi.2017.5.2(14)

Marshall, A. 2006. Principles of Economics. New York, Cosimo.

Menshikov, V.; Volkova, O.; Stukalo, N.; Simakhova, A. 2017. Social economy as a tool to ensure national security, Journal of Security and Sustainability Issues 7(2): 211-231. https://doi.org/10.9770/jssi.2017.7.2(4)

Michael, G. Parisi. 2005. Moving Toward Transparency? An Examination of Regulatory Takings in International Law”, 19 Emory International Law Review.

Mill, J. S. 2016. Principles of Political Economy. VM eBooks.

Obukhova, A. S.; Mashkina, N. A. 2014. The Investment Climate in Russia and its Regions. Asian Social Science 10(20), $28-37$.

Ohotina, A. 2017. Investment climate in Latvia, Lithuania, Belarus cross border regions. Doctoral Thesis. Daugavpils University.

Organization for Security and Co-operation in Europe. 2006. Best-Practice Guide for a Positive Business and Investment Climate.

Perry, B. 2017. Evaluating Country Risk for International Investing. Available on the Internet: http://www.investopedia.com/articles/ stocks/08/country-risk-for-international-investing.asp

Petrenko, E.; Iskakov, N.; Metsyk, O.; Khassanova, T. 2017. Ecosystem of entrepreneurship: risks related to loss of trust in stability of economic environment in Kazakhstan, Entrepreneurship and Sustainability Issues 5(1): 105-115. https://doi.org/10.9770/ jesi.2017.5.1(8)

Petty, V.; Smith, A.; Ricardo, D. 1993. Anthology of economic classics. Key Economy.

Pietrzak, M. B.; Balcerzak, A. P.; Gajdos, A.; Arendt, L. 2017. Entrepreneurial environment at regional level: the case of Polish path towards sustainable socio-economic development, Entrepreneurship and Sustainability Issues 5(2): 190-203. https://doi.org/10.9770/ jesi.2017.5.2(2) 
Pietrzak, M.B.; Balcerzak, A. P.; Gajdos, A.; Arendt, Ł. 2017. Entrepreneurial environment at regional level: the case of Polish path towards sustainable socio-economic development. Entrepreneurship and Sustainability Issues 5(2): 190-203. http://doi.org/10.9770/ jesi.2017.5.2(2)

Pigou, A. 2005. The Economics of Welfare. Liberty Fund, Inc.

Raluca Danciu, A. 2010. Model for Evaluating Regional Competitiveness Regarding Foreign Investment Attraction. Available on the Internet: http://www.ipedr.com/vol39/029-ICITE2012-K00010.pdf.

Samuelson, A. 2010. Economics. Tata McGraw-Hill Education.

Sauka, A. 2017. FICIL Sentiment Index 2017. The Development of the Investment Climate In Latvia: The Viewpoints of Foreign Investors. Stockholm School of Economics in Riga, Foreign Investors' Council in Latvia.

Sayapin, A. V. 2011. Investment climate as display of region economic security. Available on the Internet: http://cyberleninka.ru/ article/n/investment-climate-as-display-of-region-economic-security

SIA “Investīciju Risinājumu Birojs”. 2013. Uzṇēmējdarbības vide Jūrmalas pilsētā. [Entrepreneurship Environment in Jurmala]. Available on the Internet: http://www.sif.gov.lv/nodevumi/nodevumi $/ 5115 / \mathrm{P} \% \mathrm{C} 4 \% 93 \mathrm{t} \% \mathrm{C} 4 \% \mathrm{ABjums}$ uz $\% \mathrm{C} 5 \% 86 \% \mathrm{C} 4 \% 93 \mathrm{~m} \% \mathrm{C} 4 \% 93 \mathrm{jda}$ rb $\%$ C4\%ABbas $\% 20$ vide $\% 20 J \%$ C5\%ABrmalas $\% 20$ pils $\%$ C4\%93t $\%$ C4\%81.pdf

Šimelytè, A.; Antanavičienė, J. G. 2013. Foreign Direct Investment Policy as an Instrument for Sustainable Economic Growth: a Case of Ireland. Journal of Security and Sustainability Issues, 2 (4): 25-34. https://doi.org/10.9770/jssi.2013.2.4(3)

Smith, A. 2007. An Inquiry into the Nature and Causes of the Wealth of Nations. Edited by S.M. Soares. MetaLibri Digital Library, 2007.

Titarenko, D. 2005. Neodnorodnost investitsionnogo prostranstva Latvii [Unhomogeneity of Latvia Investment Space]. Transport and Telecommunication, TTI Research Journal 6 (3), 368-377.

Titarenko, D. 2006. The Influence of Foreign Direct Investment on Domestic Investment Processes in Latvia. Transport and Telecommunication. TTI Research Journal 7(1): 76-83.

TNS Latvia. 2008. Investīciju klimats un uzṇēmējdarbības vide Latvijā [Investment Climate and Entrepreneurship Environment in Latvia]. Available on the Internet: http://www.tns.lv/newsletters/2008/18/?category=tns18\&id=MR_Uznemejdarbibas_vide

Tvaronavičienė, M; Gatautis, R. 2017. Peculiarities of income distribution in selected countries. Economics and Sociology, 10(4), 113-123. doi:10.14254/2071-789X.2017/10-4/9

Tvaronavičienė, M.; Grybaitė V.; Tunčikienė Ž. 2013. Globalization Drivers in Developed and Less Developed Countries: if Consistent Patterns can be Traced. Journal of Security and Sustainability Issues, 2(4): 5-11. https://doi.org/10.9770/jssi.2013.2.4(1)

Tvaronavičienė, M.; Kalašinskaite, K.; Šimelytė, A. 2009. Review of Approaches towards FDI: Driving Forces and Plausible Consequences. Socialinių mokslų studijos. Mokslo darbai. Social Sciences Studies. Research Papers. No. 2, issue 2, 1-7.

Tvaronavičienė, M.; Lankauskienė, T. 2011. Plausible Foreign Direct Investment' Impact on Sustainable Development Indicators of Differently Developed Countries. Journal of Security and Sustainability Issues, 1 (1): 27-38. https://doi.org/10.9770/jssi.2011.1.1(3)

Walras, L. 2003. Elements of Pure Economics. London, Routladge.

Weingast B. 1995. The Economic Role of Political Institutions: Market- Preserving Federalism and Economic Development. Journal of Law, Economics\& Organization 11 (1), 1-31.

World Bank. 2004. World Development Report 2005: A better investment climate for everyone. Washington: World Bank.

World Bank. 2005. Doing Business 2006: Creating Jobs. Washington, Oxford University Press. 


\section{About the contributors:}

Alina OHOTINA is Dr.oec, Researcher at the Institute of Humanities and Social Sciences of Daugavpils University, Latvia. She has the status of Expert of the Latvian Council of Science in the field of economics. Her research interests: regional economics, investments, investment climate (entrepreneurial enviroment).

Olga LAVRINENKO is Dr.oec, Leading researcher at the Institute of Humanities and Social Sciences of Daugavpils University, Latvia. She has the status of Expert of the Latvian Council of Science in the field of economics. Her research interests: regional economics, sustainable economic development.

Svetlana IGNATJEVA is Dr. Phys. Head of Computer Science Department of Daugavpils University, gives lectures and participates in research at Tyumen State University as a visiting foreign specialist. Research interests: development and adaptation of questionnaires; collection, analysis and data processing using Data Mining methods.

Jẹ̦ena LONSKA is Dr.oec, Researcher, Docent at Rezekne Academy of Technologies. She has the status of Expert of the Latvian Council of Science in the field of economics. Her research interests: regional economics, territorial development. 